\title{
ARTICLE
}

\section{Extraction, Characterization and Rheological Behavior of Tamarind Gum Under High Salinity}

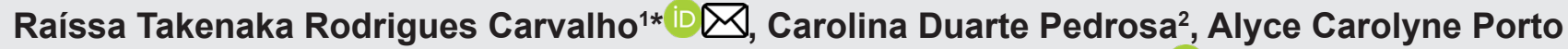 \\ Leal $^{2}$, Luiz Carlos Magalhães Palermo², Claudia Regina Elias Mansur ${ }^{1}$ iD \\ ${ }^{1}$ Universidade Federal do Rio de Janeiro - Programa de Engenharia Metalúrgica e de Materiais (PEMM/ \\ COPPE) and Instituto de Macromoléculas (IMA). Cidade Universitária, Rua Moniz Aragão, 360. Bloco 8G-CT2. \\ CEP 21941-594 - Rio de Janeiro, RJ, Brazil \\ 2Universidade Federal do Rio de Janeiro - Instituto de Macromoléculas (IMA). Cidade Universitária, Rua Moniz \\ Aragão, 360. Bloco 8G-CT2. CEP 21941-594 - Rio de Janeiro, RJ, Brazil
}

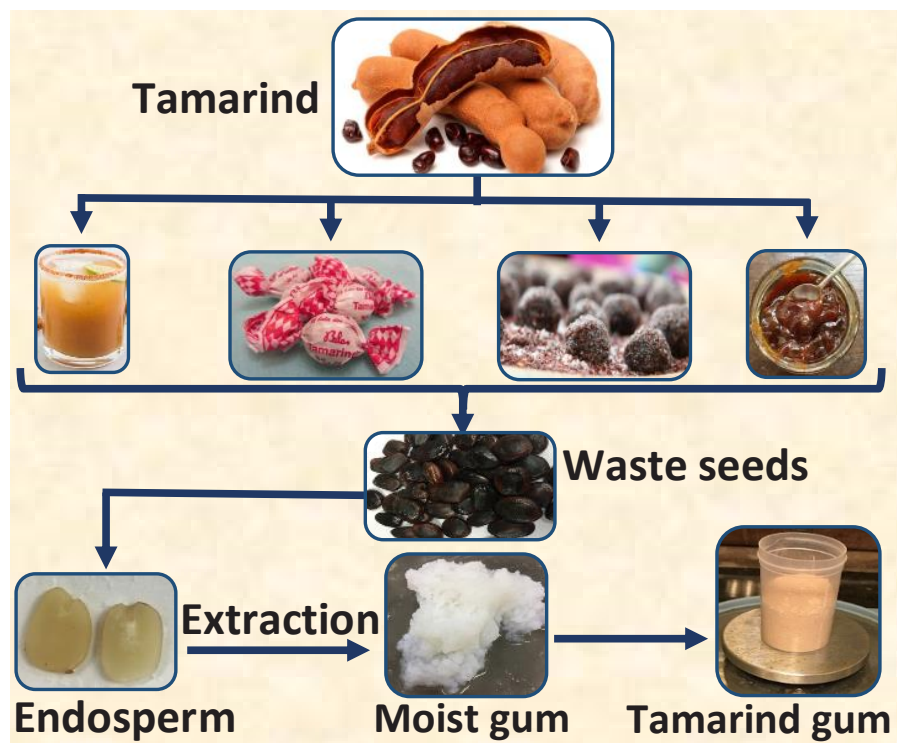

The objective of this work was to obtain tamarind gum from Tamarindus indica $\mathrm{L}$. seeds, which are waste from the food industry. Tamarind gum was extracted by two methods and the highest yield achieved was $32.6 \% \mathrm{w} / \mathrm{w}$, containing $69.25 \%$ w/w of organic matter, which was composed mostly of the nonionic polysaccharide xyloglucan. The greatest molar mass of the tamarind gum was $\mathrm{Mw}=7.16 \times 10^{5} \mathrm{~g} \mathrm{~mol}^{-1}$ with polydispersity index $(\mathrm{PI})$ of 1.7. Evaluation of the rheological behavior of tamarind gum samples were carried out in two brines (total dissolved solids values of $29,711 \mathrm{mg} \mathrm{L}^{-1}$ and $68,317 \mathrm{mg} \mathrm{L}^{-1}$, containing divalent ions) that simulated petroleum reservoir salinity levels, with different temperatures $(25,60$ and $80{ }^{\circ} \mathrm{C}$ ). The rheological curves indicated high salt resistance of the gum samples. Under a shear rate of $7.3 \mathrm{~s}^{-1}$ the highest viscosity values found were approximately 86, 41 and $50 \mathrm{cP}$ with a concentration of $5,000 \mathrm{ppm}$ and temperatures of 25,60 and $80^{\circ} \mathrm{C}$, respectively.

Keywords: Xyloglucan, Biopolymer, Tamarind seeds, Rheology, Harsh reservoir conditions.

\section{INTRODUCTION}

Biopolymers can be derived from plant, animal or microbial biomass. These may be polysaccharides, lipopolysaccharides, glycolipids, proteins or polyhydroxyalkanoates [1]. Many complex polysaccharides are found in nature, among which xyloglucans are potentially useful for various purposes [2].

Cite: Carvalho, R. T. R.; Pedrosa, C. D.; Leal, A. C. P.; Palermo, L. C. M.; Mansur, C. R. E. Extraction, Characterization and Rheological Behavior of Tamarind Gum Under High Salinity. Braz. J. Anal. Chem. 2022, 9 (35), pp 62-75. http://dx.doi. org/10.30744/brjac.2179-3425.AR-104-2021 
Xyloglucans are hemicelluloses that occur in the primary cell walls of all vascular plants, as well as in different seeds, such as Tamarindus indica L., Impatiens balsamina, among others. Its chemical structure is formed by a $\beta-(1 \rightarrow 4)$-glucan backbone substituted with $\alpha-(1 \rightarrow 6)$-xylosyl residues in a regular pattern, as well as occasional galactosyl or fucosyl residues [3,4].

Xyloglucans can be extracted from tamarind seeds or from waste pulp after fruit processing, containing as high as $72 \%$ wt of biopolymers [5]. Tamarind xyloglucan (also called tamarind gum) is used as a thickening agent in foods, pharmaceuticals and cosmetics [6]. Besides these traditional industrial applications, new functionalities have been proposed for native and modified xyloglucans [7], such as textile production, tissue engineering, wastewater treatment, food processing (emulsifiers, stabilizers, gelling agents), paste materials and freshness-maintaining agents, among others $[8,9]$.

In addition to the applications mentioned above, biopolymers in general are being studied for application in polymer flooding that is a broadly applied enhanced oil recovery (EOR) method. Where synthetic polymers, which are generally based on partially hydrolyzed polyacrylamide (HPAM), have presented low salinity resistance, mainly in the presence of divalent cations $\left(\mathrm{Ca}^{2+}\right.$ and $\left.\mathrm{Mg}^{2+}\right)$, which in some systems can cause premature polymer precipitation $[10,11]$.

The polymer function in the EOR injection fluid is to increasing its viscosity, resulting in mobility control, enabling a larger sweep area, increasing the oil recovery efficiency.

Biopolymers are less susceptible to high salinity, so they have been considered promising for this application [12].

In this study, a new potential application of tamarind gum extracted from Tamarindus indica seeds, an untapped waste material of tamarind pulp processing, was evaluated. Tamarind is an abundant resource in Brazil, so additional applications of it can promote economic development of production areas. After extraction, biomolecules were characterized and their rheological behavior under harsh reservoir conditions never related before (high salinity and temperature) was evaluated to assess their potential as viscosifying agents for EOR application.

\section{MATERIALS AND METHODS Materials}

The Tamarindus indica seeds were obtained from the company Arbocenter Comércio Sementes (São Paulo, Brazil). Sodium chloride, calcium chloride anhydrous, magnesium chloride hexahydrate, potassium chloride, sodium sulfate anhydrous, strontium chloride hexahydrate all P.A/A.C.S from Synth, Brazil. Dimethyl sulfoxide-d6 (99.9 atom\%D) from Sigma-Aldrich (São Paulo, Brazil); polyethylene oxide standard 99\% from PolyAnalytik (São Paulo, Brazil); and ethanol P.A (99.8\%) from Isofar (Rio de Janeiro, Brazil).

\section{Experimental methods}

Determination of tamarind seed kernel

Storage xyloglucans is the most abundant polysaccharide from the group of hemicelluloses and they are found in the cotyledons of some leguminous seeds such as Tamarindus indica $[13,14]$. Tamarind seeds were weighed and then placed in the oven at $80{ }^{\circ} \mathrm{C}$ until reaching constant weight (dry seed weight). Subsequently, the seed hulls were removed to isolate all seed kernel, which were dried under the same condition described above (dry seed kernel weight). All experiments were performed in duplicate and the seed kernel (cotyledons) was calculated by Equation 1

$$
\text { Content of tamarind seed kernel }(\%)=\frac{\text { mass of gry seed kernel }}{\text { mass of dry seed }} x 100 \quad \text { (Equation 1) }
$$


Tamarind gum extraction from Tamarindus indica seeds

The tamarind gum was extracted by two methods. Method A described by Arruda et al. [15] with some modifications. The tamarind seeds $(100 \mathrm{~g})$ were washed and boiled in distilled water at $100{ }^{\circ} \mathrm{C}$ for 4 hours for enzyme inactivation and hull softening. The seeds coat were removed, seeds kernel was ground with $0.1 \mathrm{~mol} \mathrm{~L}^{-1} \mathrm{NaCl}[15 \%(\mathrm{w} / \mathrm{v})]$ at $25^{\circ} \mathrm{C}$ in a blender and the crude extract obtained was then centrifuged twice for 20 min at 4,000 rpm.

The supernatant was precipitated with $95 \%$ ethanol [1:3 (v/v)] for 15 minutes and the solid material was separated with a standard sieve $(45 \mu \mathrm{m})$, washed with ethanol [1:3 (w/v)] for $30 \mathrm{~min}$ and tamarind gum was isolated again with the same standard sieve. Lastly, it was lyophilized and powdered.

Method B was performed as described by Sousa et al. [16] with a few adjustments. The seeds were weighed $(40 \mathrm{~g})$ and soaked for swelling in deionized water at $40 \mathrm{~g} \mathrm{~L}^{-1}$ for 12 hours at $8{ }^{\circ} \mathrm{C}$, to extract the xyloglucan. Then the seeds were separated by filtration through a standard sieve $(1000 \mu \mathrm{m})$ and the liquid phase was centrifuged at 4,000 rpm for 20 minutes. Next, the seeds were boiled in deionized water at 100 ${ }^{\circ} \mathrm{C}$ for 2 hours for enzyme inactivation, hull softening and first hot aqueous extraction. After that, this blend (crushed seeds and deionized water) was ground, boiled for another hour and ground again. This was followed by two centrifugations at 4,000 rpm for 10 minutes each to separate the particulate matter. The extract obtained was subsequently precipitated in ethanol $(1: 3 \mathrm{v} / \mathrm{v})$ under slow stirring, washed with $95 \%$ ethanol, filtered through a standard sieve $(45 \mu \mathrm{m})$ and then lyophilized.

\section{Proton magnetic resonance spectroscopy $\left({ }^{1} \mathrm{H}-\mathrm{NMR}\right)$}

The tamarind gums were characterized by ${ }^{1} \mathrm{H}-\mathrm{NMR}$ using a Varian Mercury VX 300 spectrophotometer, equipped with a $5 \mathrm{~mm}$ universal probe, at spectral width of $4800 \mathrm{~Hz}$, acquisition time of $2.5 \mathrm{~s}$, pulse width calibration of 90 degrees, pulse intervals of $10 \mathrm{~s}$, transient number 80 and temperature of $60{ }^{\circ} \mathrm{C}$. The samples were solubilized in deuterated dimethyl sulfoxide $\left(\mathrm{C}_{2} \mathrm{D}_{6} \mathrm{SO}\right)$ at concentration of $12.5 \mathrm{mg} \mathrm{mL}^{-1}$.

\section{Fourier-transform infrared spectroscopy (FTIR)}

The samples for FTIR analysis were analyzed in pellet form, prepared with $5 \mathrm{mg}$ of tamarind gum and $15 \mathrm{mg}$ of $\mathrm{KBr}$. A PerkinElmer Frontier FT-IR/FIR spectrometer with triglycine sulfate (TGS) detector was employed with operating parameters of 20 scans, $4 \mathrm{~cm}^{-1}$ resolutions, and wavelength from 4000 to 400 $\mathrm{cm}^{-1}$.

Thermogravimetric analysis (TGA) and derivative thermogravimetry (DTG)

Thermogravimetric analyses were carried out to correlate the tamarind gum mass loss temperatures with the composition and purity of the samples. The equipment used was a TA Instruments TGA Q500 analyzer and the conditions used were nitrogen atmosphere $(\geq 99.99)$, heating rate of $10{ }^{\circ} \mathrm{C} / \mathrm{min}$ and maximum temperature of $700^{\circ} \mathrm{C}$. Initial mass of Method A was $20.6680 \mathrm{mg}$ and Method B was $9.3190 \mathrm{mg}$.

\section{Elemental analysis (CHN)}

An elemental analysis ( $\mathrm{CHN}$ ) was performed to verify the presence of nitrogen in the tamarind gum samples and thus calculate the protein concentration in the final product, using Equation 2 . For this purpose, gum samples weighing approximately $3 \mathrm{mg}$ were analyzed with a PerkinElmer 2400 series II CHNS/O elemental analyzer [17].

$$
\% \text { Protein }=\mathrm{N} \% \times 6.25 \quad \text { (Equation 2) }
$$

\section{Size-exclusion chromatography (SEC)}

First of all, the specific refractive index increment $(\mathrm{dn} / \mathrm{dc})$ of tamarind gum was calculated. For this, a stock solution was prepared in the mobile phase $\left(0.1 \mathrm{M} \mathrm{NaNO}_{3}+0.0025 \%\right.$ sodium azide, in deionized water) and filtered through a $0.45 \mu \mathrm{m}$ filter unit (Millipore). The dilutions were obtained in the range 
between 0.05 to $2.5 \mathrm{mg} \mathrm{mL}^{-1}$, according to the detection limit of the detection system composed of a Wyatt Technology DAWN8+ multi-angle light scattering detector and Wyatt Technology Optilab T-rEX refractive index detector. Subsequently, for SEC analysis the stock solutions were passed through $0.45 \mu \mathrm{m}$ and 0.22 $\mu \mathrm{m}$ filters (Millipore) and injected into an Agilent Technologies 1260 Infinity gel permeation chromatograph with a Shodex LG-G 6B pre-column and two Shodex LB- 806M columns and the detectors described before.

Low molecular weight poly(ethylene oxide) was used as standard and the analysis temperature was 40 ${ }^{\circ} \mathrm{C}$ with flow rate of $0.5 \mathrm{~mL} / \mathrm{min}$. The data were processed with the Astra 1.7.3 software to obtain $\mathrm{Mw}, \mathrm{Mn}$ and the polydispersity values relative to the tamarind gum.

\section{$X-R a y$ diffraction analysis (XRD)}

This technique was used to identify the tamarind gum morphology. After being ground the samples were passed through a 170 mesh sieve to standardize the mesh. Subsequently, they were compacted in a specific sample holder and evaluated with a Proto AXRD benchtop diffractometer with wavelength $\lambda=$ $0.1542 \mathrm{~nm}$, corresponding to CuKa radiation. The samples were analyzed in stepwise mode at angular amplitude from $7^{\circ}$ to $90^{\circ}(2 \theta)$, with resolution of $0.04^{\circ}$, speed of $0.05^{\circ} \mathrm{sec}^{-1}, 30 \mathrm{kV}$ and $20 \mathrm{~mA}$.

\section{Rheological behavior}

The rheological behavior of tamarind gum was carried out with a TA Instruments DHR3 rotational rheometer with titanium cone/plate accessory $\left(40 \mathrm{~mm}^{\circ}\right)$ and TA Instruments TRIOS software. Flow curves were obtained with shear rates ranging from 0.1 to $100 \mathrm{~s}^{-1}$ with two different synthetic brines: water I (WI), which simulated seawater used as injection with total dissolved solids (TDS) equal to $29,711 \mathrm{mg} \mathrm{L}^{-1}$; water II (WII), with TDS $=68,317 \mathrm{mg} \mathrm{L}^{-1}$, which simulated a mixture of injection water and formation water with high salinity. The composition of $\mathrm{WI}$ was $\mathrm{NaCl} 27,936 \mathrm{mg} \mathrm{L}^{-1}$, anhydrous $\mathrm{CaCl}_{2} 372 \mathrm{mg} \mathrm{L}^{-1}, \mathrm{MgCl}_{2} \cdot 6 \mathrm{H}_{2} \mathrm{O}$ $1,275 \mathrm{mg} \mathrm{L}^{-1}, \mathrm{KCl}_{748} \mathrm{mg} \mathrm{L}^{-1}$, and $\mathrm{Na}_{2} \mathrm{SO}_{4} 58 \mathrm{mg} \mathrm{L}^{-1}$, while that of WII was $\mathrm{NaCl} 55,306 \mathrm{mg} \mathrm{L}^{-1}$, anhydrous $\mathrm{CaCl}_{2} 7971 \mathrm{mg} \mathrm{L}^{-1}, \mathrm{KCl} 1,569 \mathrm{mg} \mathrm{L}^{-1}, \mathrm{Na}_{2} \mathrm{SO}_{4} 72 \mathrm{mg} \mathrm{L}^{-1}$, and $\mathrm{SrCl}_{2} \cdot 6 \mathrm{H}_{2} \mathrm{O} 1703 \mathrm{mg} \mathrm{L}^{-1}$.

The tamarind gum concentrations used were 2,000,3,000 and 5,000 ppm and the analyses were carried out at three temperatures, ambient temperature $\left(25^{\circ} \mathrm{C}\right)$ and $60^{\circ} \mathrm{C}$ [18] and $80^{\circ} \mathrm{C}$ [19] to simulate typical injection and reservoir temperatures.

\section{RESULTS AND DISCUSSION \\ Seed kernel content}

The evaluated tamarind seeds showed $67 \% \mathrm{w} / \mathrm{w}$ of its weight being the seed kernel, which is the part of the seed with highest biopolymer concentration. How higher is seed kernel percentage better will be the biopolymer source because xyloglucan is obtained from tamarind kernel. Therefore, tamarind seeds presented a high potential for biopolymer production.

\section{Extraction yield (\% w/w)}

The yield of each extraction was calculated by dividing the final product weight by the initial dry weight of seeds, expressed as \% w/w. The yields were $7.7 \%$ (method A) and $32.6 \%$ (method B).

Method B produced the highest yield $(32.6 \% \mathrm{w} / \mathrm{w})$, possibly due to the performance of a sequential aqueous extraction process, one cold and two hots. This yield was higher than found by Alpizar-Reyes et al. [5], of $29.83 \% \mathrm{w} / \mathrm{w}$, and by Singh et al. [20], of $18.39 \% \mathrm{w} / \mathrm{w}$, but it was less than found by Sousa et al. [16], of $40.63 \% \mathrm{w} / \mathrm{w}$. These yield variations are frequent and depend on factors such as geographical origin, variety and growing conditions, besides the conditions and stages of the extraction process, as mentioned by Shao et al. [21]. 
Proton nuclear magnetic resonance spectroscopy $\left({ }^{1} \mathrm{H}-\mathrm{NMR}\right)$

As mentioned before, xyloglucan is a polysaccharide with a complex structure consisting of a main chain formed by D-glucopyranose units, linked by $\beta$-type glycosidic bonds $(1 \rightarrow 4)$, with O-6 substituted side units in O-6 per unit of $\alpha$-D-xylopyranose, which may also be substituted at O-2 by $\beta$-D-galactopyranose units [7]. Figure 1 shows the ${ }^{1} \mathrm{H}-\mathrm{NMR}$ spectrum of gum extracted from Tamarindus indica seeds, indicating its composition mostly of xyloglucan. All the ${ }^{1} \mathrm{H}-\mathrm{NMR}$ spectra showed typical characteristic polysaccharides signals, in a narrow region between 3 and 5 ppm, indicating the presence of sugar residues [22].
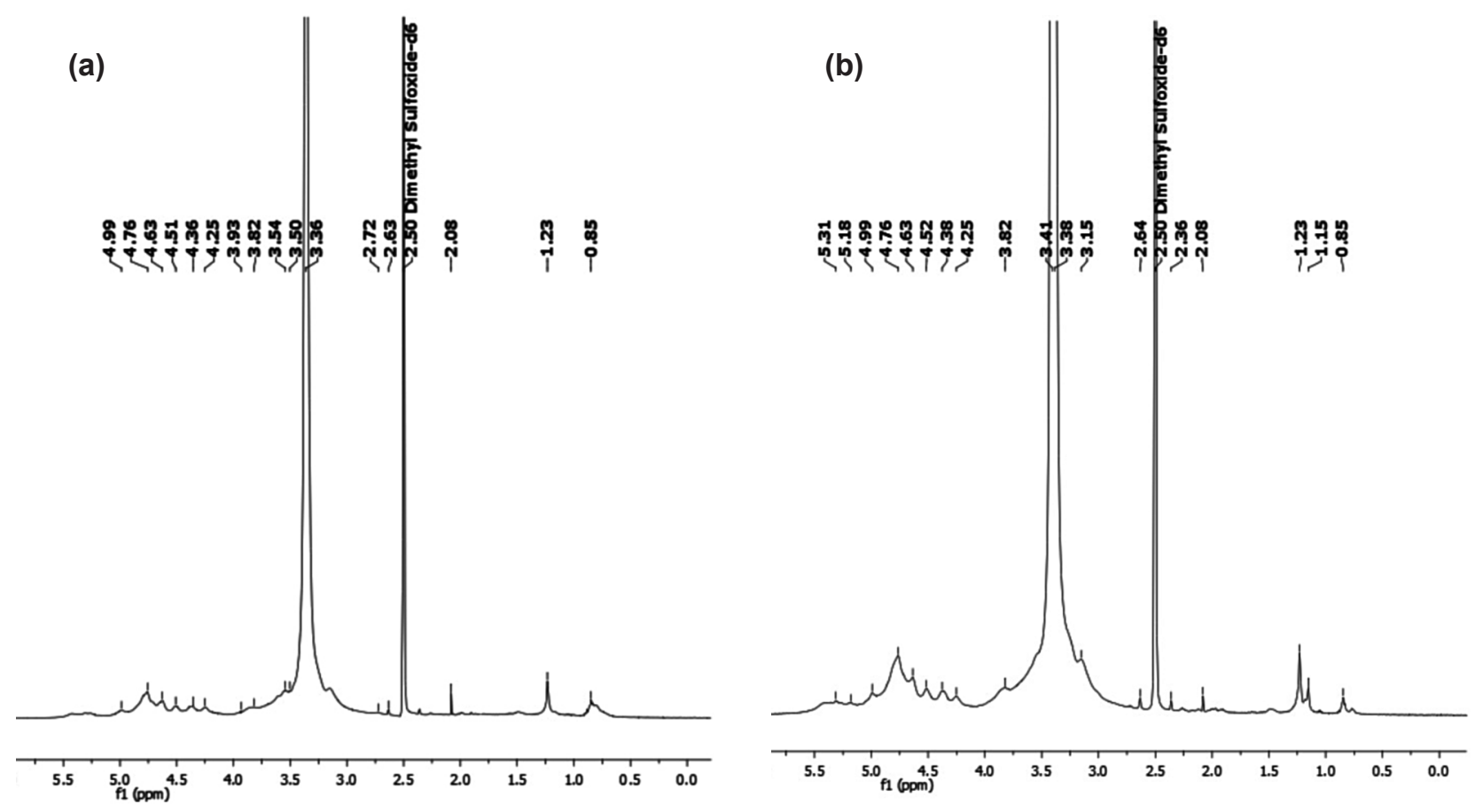

Figure 1. ${ }^{1} \mathrm{H}$ NMR spectrum of tamarind gum from (a) method $A$ and $(b)$ method $B$.

Figure 1 also indicates the presence of peaks between 4.0 and 5.5 ppm, referring to the anomeric hydrogens related to the polysaccharides [23]. Within this region, one can observe the anomeric $\alpha$ and $\beta$ hydrogens, but unfortunately the signals of carbohydrates in NMR spectra are frequently crowded in a narrow region, especially in the case of complex carbohydrates. As a result, the interpretation of ${ }^{1} \mathrm{H}-\mathrm{NMR}$ spectra is difficult if a polysaccharide contains many similar sugar residues [24]. The other peaks located in the region of low chemical displacement $(0.8$ to $2.0 \mathrm{ppm})$ are related to the methyl and methylene groups of remaining impurities in the extraction process, such as ethanol [25].

\section{Fourier-transform infrared spectroscopy (FTIR)}

The FTIR analysis was carried out to corroborate the structure of the xyloglucan extracted from the Tamarindus indica seeds (Figure 2). The chemical structure identified for method A and B was very similar but not the same because minor differences can be observed in the peak intensities. The main peak assignments were: $\mathrm{O}-\mathrm{H}$ stretching vibration for broad peak between $3000-3700 \mathrm{~cm}^{-1}$ (could be related to water and/or the xyloglucan), $\mathrm{CH}_{2}$ or $\mathrm{CH}_{3}$ stretching (2900 - $\left.3100 \mathrm{~cm}^{-1}\right), \mathrm{C}-\mathrm{H}$ symmetric stretching (2926 $\left.\mathrm{cm}^{-1}\right)$, adsorbed water (1656 $\left.\mathrm{cm}^{-1}\right)$; amide I (1600-1700 $\left.\mathrm{cm}^{-1}\right)$ and amide II (1500-1560 $\left.\mathrm{cm}^{-1}\right)$ are prominent features of a typical protein spectrum, the first is due to $\mathrm{C}=\mathrm{O}$ stretching vibration and the second to the $\mathrm{N}-\mathrm{H}$ bending and $\mathrm{C}-\mathrm{N}$ stretching vibrations of peptide backbone; $\mathrm{CH}_{2}$ angular deformation $1470-1430$ $\mathrm{cm}^{-1}, \mathrm{CH}_{3}$ angular deformation $1390-1370 \mathrm{~cm}^{-1}, \mathrm{C}-\mathrm{N}$ axial distortion $\left(1441 \mathrm{~cm}^{-1}\right), \mathrm{C}-\mathrm{O}$ and $\mathrm{C}-\mathrm{C}$ stretching vibrations of the hexopyranosyl skeleton $\left(1040 \mathrm{~cm}^{-1}, 943 \mathrm{~cm}^{-1}, 896 \mathrm{~cm}^{-1}\right)$ [26-32]. 


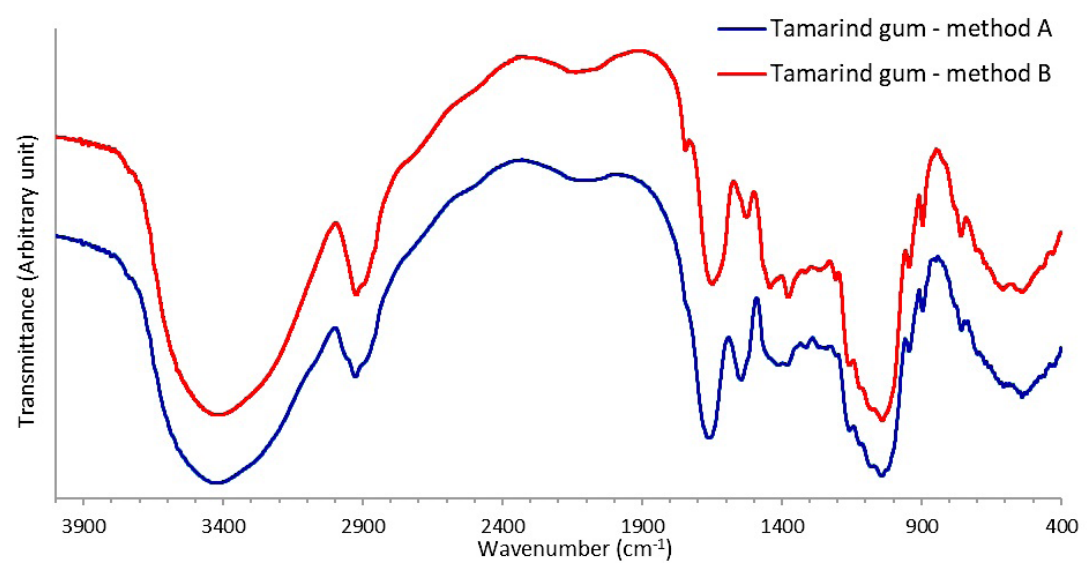

Figure 2. FTIR spectra of tamarind gum produced by method A and B.

The FTIR spectra in Figure 2 are typical for xyloglucan and peaks between 400 and $1000 \mathrm{~cm}^{-1}$ consists of fingerprint region it also has other vibrations such as $\mathrm{CH}_{2}, \mathrm{OH}, \mathrm{CO}$ deformations, etc. These were disregarded due to the high complexity in this region [33]. Among recorded peaks, changes in intensities were observed and can be attributed to protein, nucleic acids bases and fatty acids, suggesting the presence of contaminants, a possibility later ascertained by elemental analysis ( $\mathrm{CHN})$.

\section{Thermogravimetric analysis (TGA)}

Figure 3 shows TGA and DTG curves of tamarind gum extracted using methods $A$ and $B$ where two steps can be observed. In both TGA thermograms, the initial most pronounced mass loss up to $150{ }^{\circ} \mathrm{C}$ can be associated with the loss of adhered water or other volatile solvents, such as ethanol, which was used in the precipitation stage. The second event (approximately $200-500{ }^{\circ} \mathrm{C}$ ) refers to the degradation of the organic fraction biopolymer chain cleavage with a high weight loss and the extrapolated onset temperatures of the DTG curve were $257^{\circ} \mathrm{C}$ for method A and $299^{\circ} \mathrm{C}$ for method $\mathrm{B}$. These temperatures are close to those found for xyloglucan by Bergströma et al. [34] and Marais et al. [35].

The residual mass obtained at the end of analysis, at temperature of $700{ }^{\circ} \mathrm{C}$, can be correlated with the inorganic compounds, usually salts, contained in the raw material and/or from the extraction process.

According to the TGA/DTG thermograms (Figure 3), the mass losses were: for method $A-11.24 \% \mathrm{w} / \mathrm{w}$ of volatile solvents (water and alcohol), $61.77 \% \mathrm{w} / \mathrm{w}$ of organic matter and $26.99 \% \mathrm{w} / \mathrm{w}$ of inorganic matter; and for method B $-11.22 \% \mathrm{w} / \mathrm{w}$ of volatile solvents (water and alcohol), $69.25 \% \mathrm{w} / \mathrm{w}$ of organic matter, and $19.53 \% \mathrm{w} / \mathrm{w}$ of inorganic matter. Greater total mass lost, indicated by a red circle in the graphs in Figure 3 , is theoretically associated with purer tamarind seed polysaccharide. 


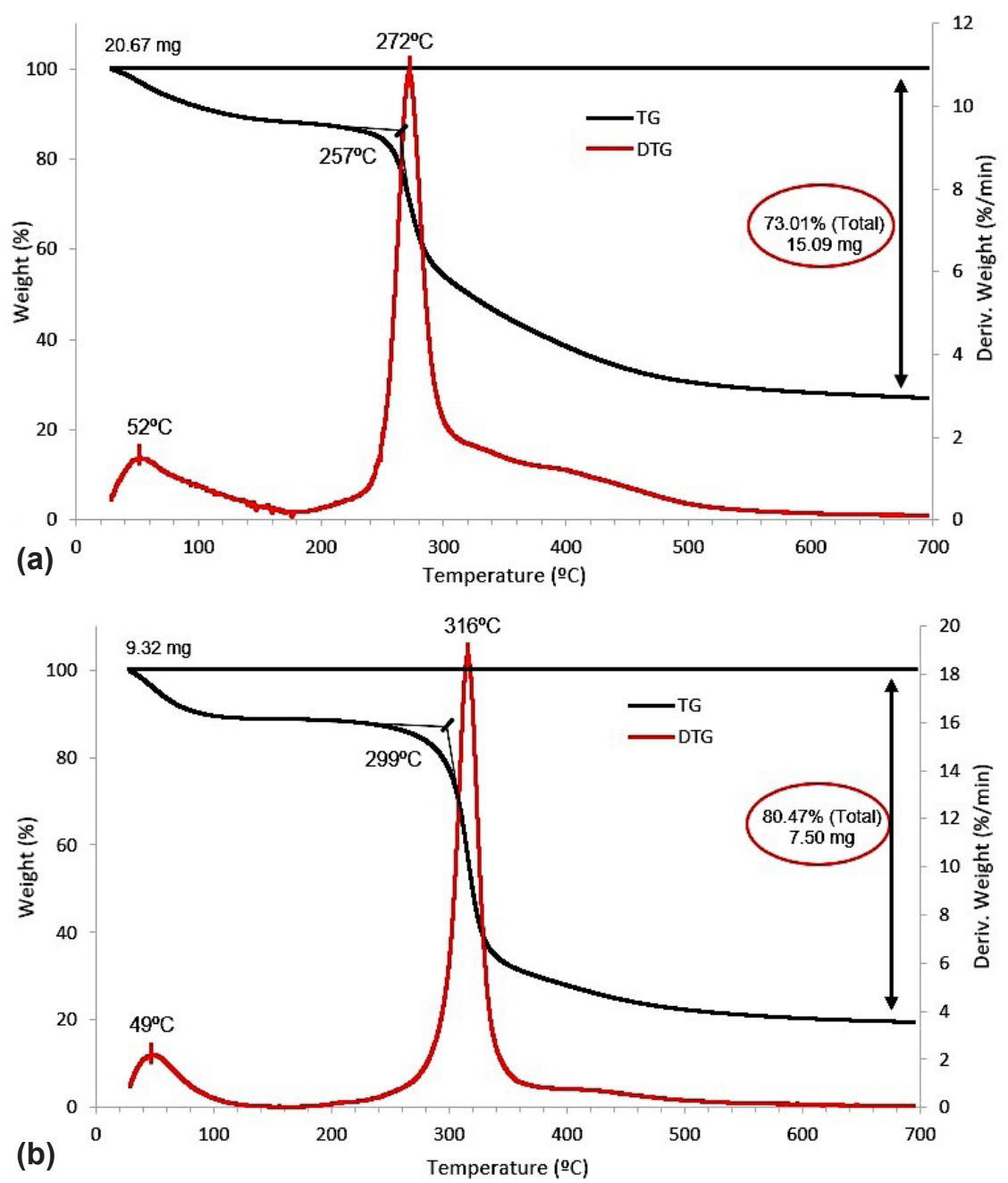

Figure 3. Thermogravimetric (black) and differential thermogravimetric curves (red) of tamarind gum extracted by (a) method $A$ and (b) method $B$.

Figure $3(\mathrm{~b})$ represents the best method $(\mathrm{B})$, which presented the highest yield $(32.2 \% \mathrm{w} / \mathrm{w})$ and the highest organic matter concentration. The total mass loss value is similar to that reported by Alpizar-Reyes et al. [36] and Khounvilay and Sittikijyothin [37], of $80.25 \%$ and $80.66 \%$ of total carbohydrates.

It should be mentioned that higher organic matter concentration is generally associated with greater efficiency in increasing the saline water viscosity.

Based on the results obtained from TGA, new yields were calculated, considering only the organic matter of interest: $4.8 \%$ (method $A$ ) and $22.6 \%$ w/w (method B). Compared with other published studies $[25,38]$, the final extraction yield of polysaccharide was lower, but this determination procedure followed our methodology described in previous work [39].

\section{CHN analysis}

Through this analysis, the presence or absence of proteins adhered to the tamarind gum was determined. Since the primary structure contains no nitrogen, the analysis allows verifying the purification process efficiency. According to the manufacturer, the equipment Limit of Detection (LOD) is $0.3 \%$, meaning that concentrations equal or below this value are considered to indicate absence of a certain chemical element. The analyses were carried out in duplicate and the results are shown in Table I. 
Table I. CHN analysis results for extracted biopolymers

\begin{tabular}{lccccc}
\hline Sample & Carbon (\%) & Hydrogen (\%) & Nitrogen (\%) & Total (\%) & Protein (\%) \\
\hline Tamarind gum method A & 37.65 & 7.25 & 3.64 & 48.50 & 20.88 \\
Tamarind gum method A & 37.67 & 6.61 & 3.61 & 47.90 & 20.69 \\
Tamarind gum method B & 39.71 & 6.92 & 0.89 & 47.50 & 3.69 \\
Tamarind gum method B & 40.00 & 7.20 & 0.90 & 48.10 & 3.75 \\
\hline
\end{tabular}

Method A produced gum with the highest protein concentration, making it less efficient in terms of protein-free gum production. Method B, on the other hand, produced gum with protein content of 3.7\%, lower than the values reported by Alpizar-Reyes et al. [36], 14.24\%, Khounvilay and Sittikijyothin [37], $13.51 \%$ and Jones and Jordan [40], 17-19\%.

Lower protein content means greater content of other substances, such as high molar mass carbohydrates. This increases aqueous solutions viscosity, meaning greater thickening efficiency of the gum.

\section{Size-exclusion chromatography (SEC)}

The $\mathrm{dn} / \mathrm{dc}$ found was $0.1453 \mathrm{~mL} \mathrm{~g}^{-1}$ for method B, which is in the range of values calculated by Sawadaa et al. [41] and Patel et al. [42], of $0.141 \mathrm{~mL} \mathrm{~g}^{-1}$ and $0.153 \mathrm{~mL} \mathrm{~g}^{-1}$, respectively. The $\mathrm{dn} / \mathrm{dc}$ of the tamarind gum obtained from method $B$ was used to determine de number average molar weight (Mn), weight average molar weight $(\mathrm{Mw})$ and polydispersity index $(\mathrm{Mw} / \mathrm{Mn})$ of the tamarind gum, obtained through methods $A$ and $B$, were:

$$
\begin{aligned}
& \text { Method } \mathrm{A}: \mathrm{Mn}=2.03 \times 10^{5}, \mathrm{Mw}=3.66 \times 10^{5} \text { and } \mathrm{Mw} / \mathrm{Mn}=1.8 \\
& \text { Method } \mathrm{B}: \mathrm{Mn}=4.161 \times 10^{5}, \mathrm{Mw}=7.16 \times 10^{5} \text { and } \mathrm{Mw} / \mathrm{Mn}=1.7
\end{aligned}
$$

These Mw values are in agreement with those obtained by Freitas et al. [6] of $8.7 \times 10^{5} \mathrm{~g} / \mathrm{mol}$, and Newton, Indana and Kumar [43], between $1.15 \times 10^{5} \mathrm{~g} / \mathrm{mol}$ and $6.5 \times 10^{5} \mathrm{~g} / \mathrm{mol}$.

Method B produced the highest concentration of organic matter and also the highest Mw value $(7.16 \mathrm{x}$ $\left.10^{5} \mathrm{~g} \mathrm{~mol}^{-1}\right)$, indicating that the sequential extraction method used favored obtaining molecules with greater molar mass.

The two methods to determine polydispersity studied are similar to those described by Freitas et al. [44] with values between 1.4 and 1.7 for xyloglucans extracted from different seeds, including tamarind seeds.

\section{$X$-ray powder diffraction (XRD)}

X-ray diffractometry was used to investigate the samples composition. Figure 4 shows the XRD pattern of tamarind gum obtained by methods $A$ and $B$. The observed profile is characteristic of amorphous materials, indicated by the absence of sharp peaks in the entire $2 \theta$ limit range. These are in accordance with the literature for xyloglucans (Arruda et al. [15], Kaur et al. [45], Madgulkar et al. [46], Mahajan et al. [47]). 


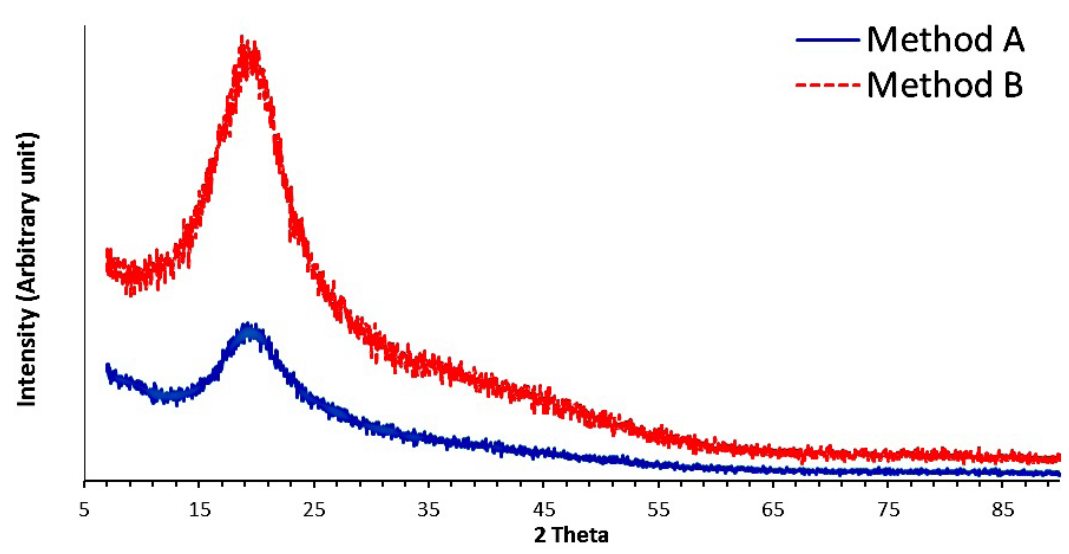

Figure 4. X-ray diffraction pattern of tamarind gum samples obtained by different methods.

\section{Rheological and solution characteristics}

Shear behavior, effect of concentration and salinity on viscosity

The curves in Figure 5 show a pseudoplastic fluid behavior, which is characterized by a reduction of viscosity with rising shear rate. This behavior is typical of high molar mass molecules, such as polymers and biopolymers. This reduction in viscosity is observed, because when the sample is shear-free, the macromolecule chains are tangled, causing high flow resistance and hence high viscosity. When shear is applied, the molecules disentangle and align in the same flow direction. This (re)organization of the biopolymer chains causes pseudoplastic behavior (Xu et al. [48]).

Figures 5 (a) and (b) show that the biopolymers prepared with water I had smaller viscosities than those prepared in water II. Therefore, in these cases higher water salinity was associated with greater viscosities. Other authors have also reported the same behavior of some biopolymers and explained this by high ionic strength of the water and changes in the conformation of macromolecules (Al-Saleh et al. [49], Diaz, Vendruscolo and Vendruscolo [50], Rodrigues et al. [14])

Between the two extraction methods, the sample obtained by method B (Figure 5.b) had the highest viscosity at the dosage of $5,000 \mathrm{ppm}$ in the water with highest salinity. This behavior is in accordance with the results shown in the thermogravimetric and molar mass determination analyses, because method $B$ presented the highest percentage of organic matter $(69.25 \% \mathrm{w} / \mathrm{w})$ and molecules with higher molar masses $\left(\mathrm{Mn}=4,161 \times 10^{5} \mathrm{~g} \mathrm{~mol}^{-1}\right.$ and $\left.\mathrm{Mw}=7.16 \times 10^{5} \mathrm{~g} \mathrm{~mol}^{-1}\right)$. 

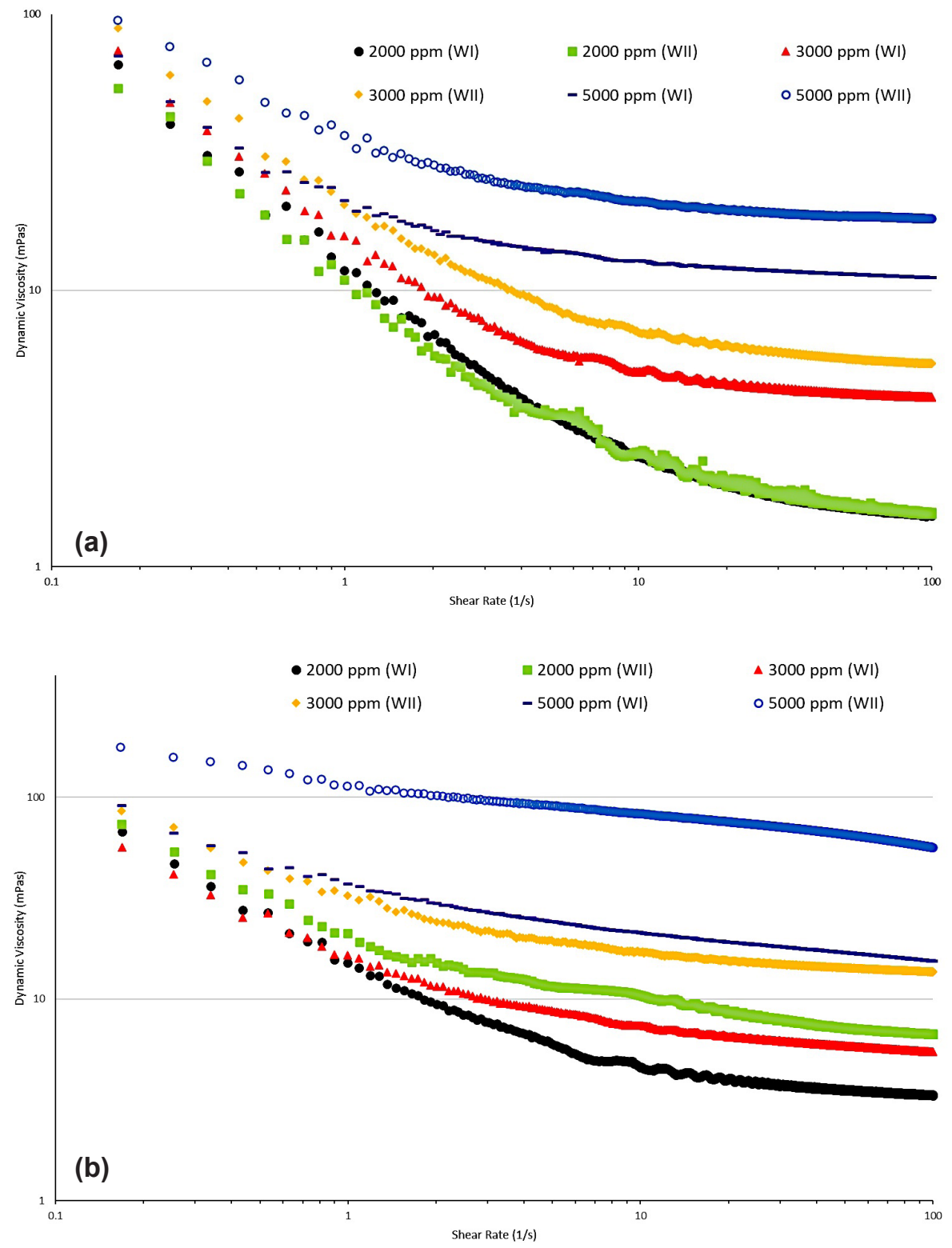

Figure 5. Flow curves of tamarind gum extracted by (a) method $A$ and (b) method $B$ at different concentrations $(2000,3000$ and 5000 ppm), two synthetic brines $(\mathrm{WI}$ and $\mathrm{WII})$ at the same temperature $\left(25^{\circ} \mathrm{C}\right)$.

Effect of temperature on the biopolymer viscosity (temperature tolerance)

In order to study the temperature influence on the solutions prepared with the extracted tamarind gum, rheological flow curves were plotted at three different temperatures, 25, 60 and $80^{\circ} \mathrm{C}$. However, for better discussion of results, viscosities were compared at a shear rate of $7.37 \mathrm{~s}^{-1}$, which simulates the flow inside a typical reservoir (Kamal et al. [51], El-hodhoudy et al. [52]). Figure 6 represents the viscosities of the solutions prepared with tamarind gum extracted by methods $\mathrm{A}$ and $\mathrm{B}$ with different concentrations (2,000, 3,000 and 5,000 ppm), salinity (TDS 29,711 $\mathrm{mg} \mathrm{L}^{-1}$ for water I and 68,317 $\mathrm{mg} \mathrm{L}^{-1}$ for water II) and temperature $\left(25,60\right.$ and $\left.80^{\circ} \mathrm{C}\right)$. 

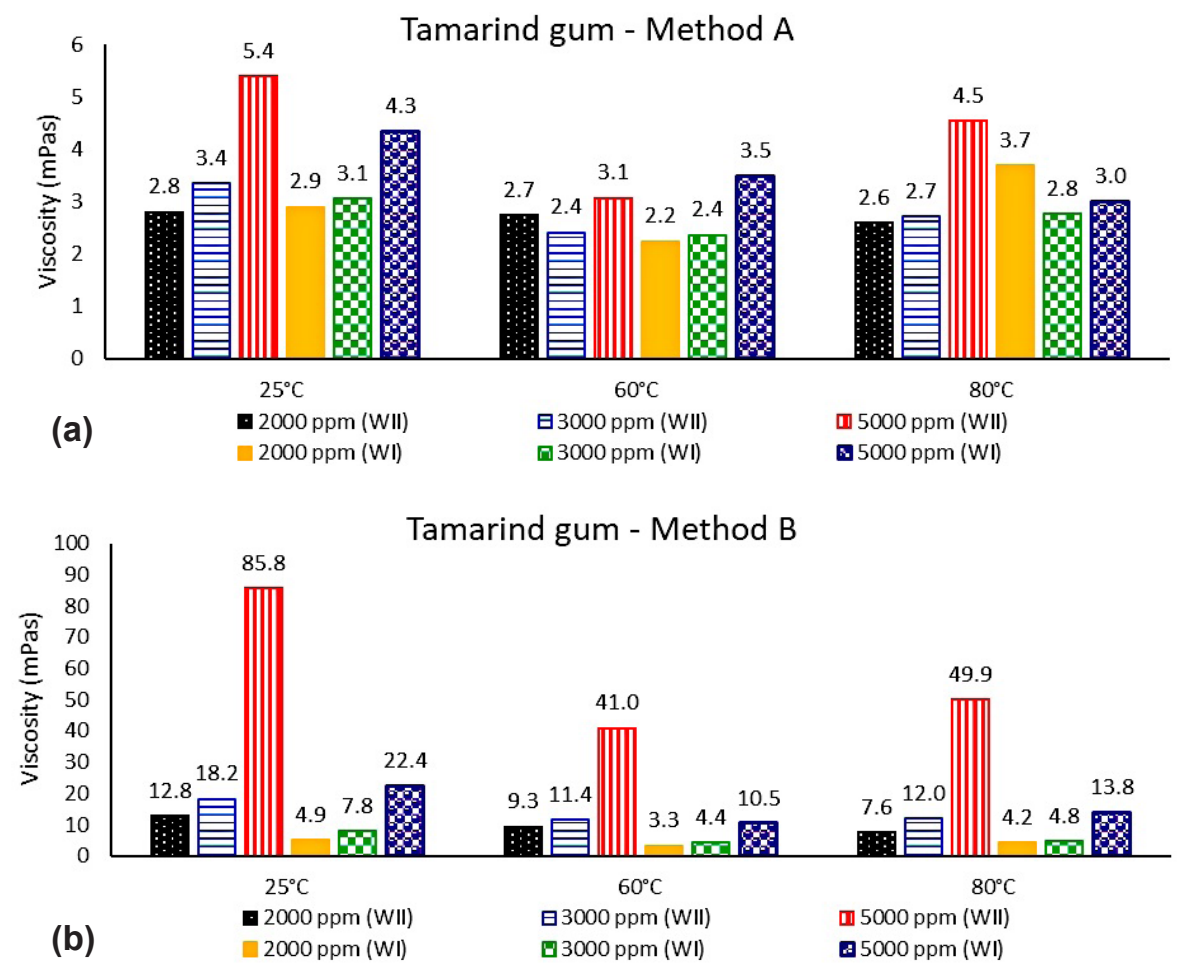

Figure 6. Viscosities of Tamarind gum solutions at shear rate of $7.3 \mathrm{~s}^{-1}$ extracted by methods (a) A and (b) B with different concentrations (2000, 3000 and 5000 ppm), salinity (TDS $29,711 \mathrm{mg} \mathrm{L}^{-1}$ for $\mathrm{WI}$ and $68,317 \mathrm{mg} \mathrm{L}^{-1}$ for WII) and temperatures $\left(25,60\right.$ and $\left.80^{\circ} \mathrm{C}\right)$.

Most of the systems illustrated in Figure 6 showed a reduction in viscosity with rising temperature, which was expected, since dynamic viscosity is directly proportional to the attraction force between molecules suggesting that they have a temperature-dependent viscosity property (Zaim et al. [53]). As the temperature increases, this attraction force decreases, also decreasing the dynamic viscosity (Canciam [54]). In the Figure 6, it is possible to observe the viscosity increase for tamarind gum when evaluated at 80 ${ }^{\circ} \mathrm{C}$, but the expected behavior was a viscosity reduction with increasing temperature. It is suggesting this behavior was due to the high analysis temperature $\left(80^{\circ} \mathrm{C}\right)$, which favored solvent evaporation, resulting in higher viscosities due to higher concentration of biopolymer.

According to Figures 6 (a) and (b), the increase in salt concentration did not result in a proportional increase in viscosity. In all of these systems, the increase in concentrations had virtually no influence on rheology, confirming the theory that these systems were in the dilute solution state.

Method B (Figure 6. B) presented the highest rheological values. The highest values with concentration of $5,000 \mathrm{ppm}$ in water $80: 20$ was $85.8,41.0$ and $49.9 \mathrm{cP}$ at temperatures of 25,60 and $80^{\circ} \mathrm{C}$, respectively. This tamarind gum proved to be advantageous compared to other polymers generally applied in EOR fluids. For example, Akbari et al. [55] evaluated the rheological properties of four polyacrylamide-based co-polymers: AN132VHM (medium $\mathrm{M}_{\mathrm{w}}$ [molecular weight], high anionicity, high sulfonation degree); FLOCOMB C7035 (high $\mathrm{M}_{\mathrm{w}}$, medium anionicity, low sulfonation degree); SUPERPUSHER SAV55 (low $\mathrm{M}_{\mathrm{w}}$, high anionicity, high sulfonation degree); and THERMOASSOCIATIF (medium $\mathrm{M}_{\mathrm{w}}$, medium anionicity, medium sulfonation degree). All were prepared at a concentration of $4500 \mathrm{ppm}$ in saline water composed of $\mathrm{CaCl}_{2}-\mathrm{NaCl}$, at $25^{\circ} \mathrm{C}$ and the viscosities at a rate of $7.37 \mathrm{~s}^{-1}$ were $60,26,36$ and $35 \mathrm{cp}$. These synthetic polymers showed significant reductions in viscosities in the presence of divalent ions, a behavior that was not observed for tamarind gum, making this biopolymer even more promising for application as a viscosifying agent in EOR fluids. It is important to highlight that there is no optimum range of polymer 
viscosity for polymer flooding and the polymer viscosity is not the same as that of oil to increase oil recovery. The water-oil mobility is essential control that depend on several parameters not only of viscosities (Guo et al. [56], Wang and Dong [57]).

\section{CONCLUSIONS}

In this work it was possible to extract tamarind gum from Tamarindus indica seeds in order to investigate its applicability as a viscosifying agent for enhanced oil recovery, and thus add economic value to these seeds, typically discarded as waste. The extracted tamarind guns were composed mainly of xyloglucantype polysaccharides, and according to the structural characterization methods performed $\left({ }^{1} \mathrm{H}-\mathrm{NMR}\right.$ and FTIR), was noted that regardless of the extraction method, the gums had similar chemical composition.

Extraction method B produced the highest yield, and thermogravimetric analysis was used to determine the final extraction yield based on the organic matter content, which was $22.6 \% \mathrm{w} / \mathrm{w}$. Furthermore, this method generated molecules with higher molar masses with $\mathrm{Mw}=7.16 \times 10^{5} \mathrm{~g} \mathrm{~mol}^{-1}$. It was also verified that this method produced gum with the lowest protein content in the final product, indicating that the purification process was efficient.

Tamarind gum extracted by method B proved to be advantageous from the standpoint of rheology for reservoir conditions when compared to other synthetic polymers generally applied in EOR fluids, due to its good resistance to high salinity with the presence of divalent salts.

\section{Conflicts of interest}

The authors declare no conflict of interest.

\section{Acknowledgements}

This research was carried out in association with the ongoing R\&D project registered as ANP 20700-1, "Desenvolvimento de biopolímeros para aplicação em recuperação avançada de petróleo" (Universidade Federal do Rio de Janeiro (UFRJ) / Shell Brasil / ANP) - Development of biopolymers for EOR application, sponsored by Shell Brasil as part of its Research and Development Investment required by the ANP.

\section{REFERENCES}

1. Kanmani, P.; Aravind, J.; Kamaraj, M.; Sureshbabu, P.; Karthikeyan, S. Bioresour. Technol., 2017, 242, pp 295-303 (https://doi.org/10.1016/j.biortech.2017.03.119).

2. Bourbon, A. I.; Pinheiro, A. C.; Ribeiro, C.; Miranda, C.; Maia, J. M.; Teixeira, J. A.; Vicente, A. A. Food Hydrocolloids, 2010, 24 (2-3), pp 184-192 (https://doi.org/10.1016/j.foodhyd.2009.09.004).

3. González-Pérez, L.; Páez-Watson, T.; Álvarez-Suarez, J. M.; Obando-Rojas, M. C.; Bonifaz-Arcos, E.; Viteri, G.; Rivas-Romero, F.; Tejera, E.; Rogers, H. J.; Cabrera, J. C. J. Soil. Sci. Plant. Nutr., 2018, 18, pp 1187-1205 (http://dx.doi.org/10.4067/S0718-95162018005003301).

4. Ajovalasit, A.; Sabatino, M. A.; Todaro, S.; Alessi, S. Carbohydr. Polym., 2018, 179, pp 262-272 (http:// dx.doi.org/10.1016/j.carbpol.2017.09.092)

5. Alpizar-Reyes, E.; Carrillo-Navas, H.; Gallardo-Rivera, R.; Varela-Guerrero, V.; Alvarez-Ramirez, J.; Pérez-Alonso, C. J. Food. Eng., 2017, 209, pp 68-75 (https://doi.org/10.1016/j.jfoodeng.2017.04.021).

6. Freitas, R. A.; Spier, V. C.; Sierakowski, M. R.; Nicolai, T.; Benyahia, L.; Chassenieux, C. Carbohydr. Polym., 2015, 129, pp 216-223 (https://doi.org/10.1016/j.carbpol.2015.04.066).

7. Rosário, M. M. T.; Noleto, G. R.; Petkowicz C. L. Int. J. Biol. Macromol., 2017, 105, pp 533-540 (https:// doi.org/10.1016/j.ijbiomac.2017.07.068).

8. Mukerabigwi, J. F.; Lei, S.; Wang, H.; Luo, S.; Ma, X.; Qin, J.; Huang, X.; Cao, Y. RSC Adv., 2015, 5, pp 83732-83742 (https://doi.org/10.1039/C5RA12355K).

9. Kumar, C. S.; Bhattacharya, S. Crit. Rev. Food Sci. Nutr., 2008, 48, pp 1-20 (https://doi.org/10.1080/ 10408390600948600).

10. Orodu, K. B.; Afolabi, R. O.; Oluwasijuwomi, T. D.; Orodu, O. D. J. Mol. Liq., 2019, 288 (https://doi. org/10.1016/j.molliq.2019.04.141). 
11. Oliveira, P. F.; Costa, J. A.; Oliveira, L. F. S.; Mota, L. S.; Oliveira, L. A.; Mansur, C. R. E. J. Appl. Polym. Sci., 2019, 136, pp 1-11 (https://doi.org/10.1002/app.47793).

12. Couto, M. R.; Gudiña, E. J.; Ferreira, D.; Teixeira, J. A.; Rodrigues, L. R. New Biotechnol., 2019, 49, pp 144-150 (https://doi.org/10.1016/j.nbt.2018.11.002).

13. Kozioł, A.; Cybulska, J.; Pieczywek, P. M.; Zdunek, A. Food Biophys., 2015, 10, pp 396-402 (http:// dx.doi.org/10.1007/s11483-015-9395-2).

14. Noleto, G. R.; Petkowicz, C. L. O. Med. Chem. (Los Angeles), 2016, 6 (10), pp 658-661 (https://dx.doi. org/10.4172/2161-0444.1000411).

15. Arruda, I. R. S.; Albuquerque, P. B. S.; Santos, G. R. C.; Silva, A. G.; Mourão, P. A. S.; Correia, M. T. S.; Vicente, A. A.; Carneiro-da-Cunha, M. G. Int. J. Biol. Macromol., 2015, 73, pp 31-38 (https://doi. org/10.1016/j.jjbiomac.2014.11.001).

16. Sousa, F. D.; Araújo, M. L. H.; Souza, J. R. R.; Miranda, R. S. Open Access Library Journal, 2017, 4, e3686 (http://dx.doi.org/10.4236/oalib.1103683).

17. Mariotti, F.; Tomé, D.; Mirand, P. P. Crit. Rev. Food. Sci. Nutr., 2008, 48 (2), pp 177-184 (https://doi.or $\mathrm{g} / 10.1080 / 10408390701279749)$.

18. Almeida, A., Patel, R., Arambula, C., Trivedi, J., Soares, J., Costa, G., Embiruçu, M. Paper presented at the SPE Trinidad and Tobago Section Energy Resources Conference, Port of Spain, Trinidad and Tobago, 2018, Paper Number: SPE-191257-MS (https://doi.org/10.2118/191257-ms).

19. Mahani, H.; Menezes, R.; Berg, S.; Fadili, A.; Nasralla, R.; Voskov, D.; Joekar-Niasar, V. Energy and Fuels, 2017, 31, pp 7839-7853 (https://doi.org/10.1021/acs.energyfuels.7b00776).

20. Singh, R.; Malviya, R.; Sharma, P. K. Pharmacogn. J., 2011, 3, pp 17-19 (https://doi.org/10.5530/ pj.2011.20.4).

21. Shao, H.; Zhang, H.; Tian, Y.; Song, Z.; Lai, P. F. H.; Ai, L. Molecules, 2019, 24 (7), 1218 (https://doi. org/10.3390/molecules24071218).

22. Nayak, A. K.; Pal, D.; Santra, K. Int. J. Biol. Macromol., 2016, 82, pp 1023-1027 (https://doi.org/10.1016/j. ijbiomac.2015.10.027).

23. Jonsson, H. Exploring the structure of oligo- and polysaccharides Synthesis and NMR spectroscopy studies. Doctoral thesis, 2010, Department of Organic Chemistry, Stockholm University, Stockholm, Sweden.

24. Cui, S. W. Food carbohydrates; chemistry, physical properties, and applications. Taylor \& Francis Group, Boca Raton, 2005.

25. Chawananorasest, K.; Saengtongdee, P.; Kaemchantuek, P. Molecules, 2016, 21, pp 1-9 (https://doi. org/10.3390/molecules21060775).

26. Lucyszyn, N.; Lubambo, A. F.; Matos, K. F.; Marvilla, I.; Souza, C. F.; Sierakowski, M.-R. Mater. Sci. Eng. C, 2009, 29, pp 552-558 (https://doi.org/10.1016/j.msec.2008.10.001).

27. Mishra, A.; Malhotra, A. V. Carbohydr. Polym., 2012, 87, pp 1899-1904 (https://doi.org/10.1016/j. carbpol.2011.09.068).

28. Mukaratirwa-Muchanyereyi, N.; Kugara, J.; Zaranyika, M. F. Afr. J. Biotechnol., 2016, 15, pp 897-909 (https://doi.org/10.5897/AJB2015.15068).

29. Däntl, M.; Ganter, P.; Szendrei-temesi, K.; Jiménez-solano, A.; Lotsch, V. Nanoscale Horiz., 2020, 5, pp 74-81 (https://doi.org/10.1039/C9NH00434C).

30. Universidade de São Paulo (USP), e-Disciplinas, 2021. Available at: https://edisciplinas.usp.br/ pluginfile.php/5152720/mod_resource/content/1/TABELA\%20 DE\%20VAL ORES\%20DE\%20 ABSOR\%C3\%87\%C3\%830\%20NO\%20INFRAVERMELHO.pdf [Accessed December 2021].

31. Correia, M.; Lopes, J.; Silva, R.; Rosa, I. M.; Henriques, A. G.; Delgadillod, I.; Cruz, O.; Nunes, A. J. Alzheimers Neurodegener. Dis., 2016, 2: 007 (https://doi.org/10.24966/AND-9608/100007).

32. Berezuk, M. E.; Paesano Jr., A.; Carvalho, N. M. F.; Horn Jr., A.; Arroyo, P. A.; Cardozo-Filho, L. Quim. Nova, 2012, 35 (5), pp 876-882 (https://doi.org/10.1590/S0100-40422012000500003).

33. Christou, C.; Agapiou, A.; Kokkinofta, R. J. Adv. Res., 2018, 10, pp 1-8 (https://doi.org/10.1016/j. jare.2017.12.001). 
34. Bergström, E. M.; Salmén, L.; Kochumalayil, J. J.; Berglund, L. Carbohydr. Polym., 2012, 87, pp 25322537 (http://dx.doi.org/10.1016/j.carbpol.2011.11.024).

35. Marais, A.; Kochumalayil, J. J.; Nilsson, C.; Fogelström, L.; Gamstedt, K. Carbohydr. Polym., 2012, 89, pp 1038-1043 (http://dx.doi.org/10.1016/j.carbpol.2012.03.051).

36. Alpizar-Reyes, E.; Carrillo-Navas, H.; Romero-Romero, R.; Varela-Guerrero, V.; Alvarez-Ramírez, J.; Pérez-Alonso, C. Food Bioprod. Process., 2017, 101, pp 166-176 (https://doi.org/10.1016/j. fbp.2016.11.006).

37. Khounvilay, K.; Sittikijyothin, W. Food Hydrocoll., 2012, 26, pp 334-338 (https://doi.org/10.1016/j. foodhyd.2011.03.019).

38. Mali, K. K.; Dhawale, S. C.; Dias, R. J. Res. J. Pharm. Technol., 2019, 12, pp 1745-1752 (http://dx.doi. org/10.5958/0974-360X.2019.00292.0).

39. Carvalho, R.; Pedrosa, C.; Leal, A.; Palermo, L.; Mansur, C. Int. J. Polym. Anal. Charact. 2021, 26, pp 573-592 (https://doi.org/10.1080/1023666X.2021.1930748).

40. Jones, D. A.; Jordan, W. A. US 4074043A, February 14, 1978, Gen Mills Chem Inc, USA.

41. Sawada, S.; Yukawa, H.; Takeda, S.; Sasaki, Y.; Akiyoshi, K. J. Biomater. Sci. Polym. Ed., 2017, 28, pp 1183-1198 (https://doi.org/10.1080/09205063.2017.1320827).

42. Patel, T.; Morris, G. A.; Ebringerová, A.; Vodenicarova, M.; Velebný, V.; Ortega, A.; Torre, J. G.; Harding, S. E. Carbohydr. Polym., 2008, 74, pp 845-851 (http://dx.doi.org/10.1016/j.carbpol.2008.05.006).

43. Newton, A. M. J.; Indana, V. L.; Kumar, J. Int. J. Biol. Macromol., 2015, 79, pp 290-299 (https://doi. org/10.1016/j.jibiomac.2015.03.031).

44. Freitas, R. A.; Martin, S.; Santos, G. L.; Valenga, F.; Buckeridge, M. S.; Reicher, F.; Sierakowski, M.-R. Carbohydr. Polym., 2005, 60, pp 507-514 (https://doi.org/10.1016/j.carbpol.2005.03.003).

45. Kaur, H.; Yadav, S.; Ahuja, M.; Dilbaghi, N. Carbohydr. Polym., 2012, 90, pp 1543-1549 (https://doi. org/10.1016/j.carbpol.2012.07.028).

46. Madgulkar, A. R.; Bhalekar, M. R.; Asgaonkar, K. D.; Dikpati, A. A. Carbohydr. Polym., 2016, 135, pp 356-362 (https://doi.org/10.1016/j.carbpol.2015.08.045).

47. Mahajan, H. S.; Tyagi, V. K.; Patil, R. R.; Dusunge, S. B. Carbohydr. Polym., 2013, 91, pp 618-625 (https://doi.org/10.1016/j.carbpol.2012.08.077).

48. Xu, L.; Dong, M.; Gong, H.; Sun, M.; Li, Y. Carbohydr. Polym., 2015, 121, pp 147-154 (https://doi. org/10.1016/j.carbpol.2014.12.030).

49. Al-Saleh, M. A.; Yussuf, A. A.; Jumaa, M. A.; Hammoud, A.; Al-Shammari, T. Processes, 2019, 7, pp 1-13 (https://doi.org/10.3390/pr7060339).

50. Diaz, P. S.; Vendruscolo, C. T.; Vendruscolo, J. L. S. Semin. Ciências Exatas e Tecnológicas, 2004, 25, pp 15-28.

51. Kamal, M. S.; Sultan, A. S.; Al-mubaiyedh, U. A.; Hussein, I. A. Polymer Reviews, 2015, 55, pp 491530 (https://doi.org/10.1080/15583724.2014.982821).

52. El-hoshoudy, A. N.; Desouky, S. E. M.; Al-Sabagh, A. M.; Betiha, M. A.; El-kady, M. Y.; Mahmoud, S. Egypt. J. Pet., 2017, 26, pp 779-785 (https://doi.org/10.1016/j.ejpe.2016.10.012).

53. Zaim, S.; Cherkaoui, O.; Rchid, H.; Nmila, R.; Moznine, R. Polym. Renewable Resour., 2020, 11, pp 49-63 (https://doi.org/10.1177/2041247920960956).

54. Canciam, C. A. Rev. Univ. Vale do Rio Verde, 2013, 11, pp 228-238. Available at: http://periodicos. unincor.br/index.php/revistaunincor/article/view/1125/pdf [Accessed December 2021].

55. Akbari, S.; Mahmood, S. M.; Tan, I. M.; Ghaedi, H.; Ling, O. L. Polymers, 2017, 9, pp 1-16 (https://doi. org/10.3390/polym9120647).

56. Guo, Z.; Dong, M.; Chen, Z.; Yao, J. J. Pet. Sci. Eng., 2013, 112, pp 335-340 (https://doi.org/10.1016/j. petrol.2013.11.023).

57. Wang, J.; Dong, M. J. Pet. Sci. Eng., 2009, 67, pp 155-158(https://doi.org/10.1016/j.petrol.2009.05.007). 